\title{
Ambush Marketing in Egypt's Sports Sponsorship: Preliminary Investigations
}

\section{Dr/ Ahmed Fathi Hussien Alafandi ${ }^{I}$}

\section{Background:}

Over the past decades, sport marketing has been affected by a large amount of media clutter and competition; hence, companies invest millions of dollars to become "official sponsors" of influential sporting events (18). The enormous publicity generated by such events, which draws a massive amount of consumer attention, provides a marketing opportunity for companies other than the event's official sponsors. These companies seek to associate themselves in the minds of the public with the goodwill and popularity of these events. This activity, known as "ambush marketing", poses significant legal and business challenges for sporting event organizers seeking to protect both their financial investment as official sponsors and the integrity of their sponsorship programs (19). In other words, "ambush marketing is a threat to corporate sponsorship" (14).
One reason why companies sponsor sports events is to meet their advertising goals and reach their strategic business objectives. However, sponsoring a sporting event is sometimes used as a defensive strategy to prevent competitors from sponsoring the same event. Another reason why companies sponsor sports events is self-evident; such events attract large audiences. In his study of Guinness' sponsorship of the 1999 Rugby World Cup, Simon Rines pointed out in the International Marketing Reports that the company wanted to increase the consumption of their product in target markets in the lead-up to the event, as well as during its proceedings. Guinness strived to be perceived as the dominant sponsor of the event in order to develop their brand and to maintain a special relationship with young demographics. $(3,22)$.

It can be argued that the rise of ambush marketing was

Lecturer, Department of Sports Management, Benha University. 
a direct result of the increase of private sponsorship in the sports world. Sponsoring of global-scale sporting events such as the Olympic Games and the FIFA World Cup, which attract the world's elite athletes, began with a simple structure (17). At the beginning these sporting events had an uncomplicated form of sponsorship. When the sponsorship process became more sophisticated and gave exclusive rights to sponsors, a substantial increase in the number of sponsors and forms of sponsorship appeared as a direct outcome. Therefore, ambush marketing has become a magic word for unofficial sponsors and right holders who attempt to have their companies involved in prestigious sporting events. (5) On the one hand, purchasing sponsorship rights from sporting events rights holders helps very often sponsors to attract the consumer audience's attention to their services or products. On the other, the "ambusher", who most likely is the competing sponsor, spares no effort to distract the attention from the official sponsor. Thus, by employing ambush marketing strategies, the competing sponsor endeavours to associate its brand with the event(7)

The term "ambush marketing" was first used by the media after the 1984 Los Angeles Olympics when Kodak sponsored ABC's coverage and successfully "ambushed" Fuji, the official sponsor of these Games(16).

A review of selected literature shows that there are various definitions of the term "ambush marketing" stemming from diverse points of view on the subject. For example, some researches offer the following definition: "The term of ambush marketing was initially coined to describe the activities of a company that associated itself with an event without paying the requisite fee to the event owner $(14,7)$. Others, however, employ more "descriptive" language to define this marketing phenomenon: "A form of parasite [the ambushers], feeding off the goodwill and value of the organization, they are trying to deceive the public into believing they support. Like leeches, they suck the lifeblood and goodwill out the institution," (Payne, 1991, cited in O'Reilly, N., Seguin, 
B., 2009: p. 281) (16).Finally, the term "ambush marketing" was explained as "a planned effort by an organization to associate themselves indirectly with an event in order to gain at least some of the recognition and benefits that are associated with being a sponsor," (18). To conclude this short review of different perspectives on ambush marketing, it is worth adding that "the goal of ambusher is to hijack the intrinsic values of an event and take advantage, for the least possible cost, of the interest it solicits in audiences and, finally, to improve its reputation and transfer the positive aspects of the event to its brand," (24)

Ambush marketing has been of increasingly great concern for owners and sponsors as most ambushers are targeting sponsorship rights to associate their companies to a sporting event without investing any financial resources in it (15). To better understand the business relationship between ambush marketing methods and sports sponsorship, it is worth taking a closer look at different definitions of sponsorship, one which captures its nature. Sports sponsorship is "A promotional practice that has moved from its roots as a tool for corporate donations to a highly developed course of action in which both the sponsors, or investor, and the sponsees, or property, benefit in marketing relationship"(6).More broadly, sponsorship has also been defined as "one of the elements in the promotional mix investing in the sports entity (athletes, leagues, teams, or events) to support overall organizational objectives, marketing goals, and promotional strategies," (8). A typical sponsorship agreement should have two parties, the first is a person or a company that pays fees to gain benefits from the advertising opportunity at a sports event. The second party is the "sponsored element", which refers to sponsees or rights holder, (11). Moreover, sponsorship has also been explained as "A cash and/or inkind fee paid to a property (typically a sports, entertainment, non-profit event or organization) in return for access to the exploitable commercial potential associated with the property" $(11,24)$. 
Unjust enrichment is a general equitable principle that no person should be allowed to profit at another's expense without making restitution for the reasonable value of any property, services, or other benefits that have been unfairly received and retained. Unjust enrichment has three elements. First, the plaintiff must have provided the defendant with something of value while expecting compensation in return. Second, the defendant must have acknowledged, accepted, and benefited from whatever the plaintiff provided. Third, the plaintiff must show that it would be inequitable or Unconscionable for the defendant to enjoy the benefit of the plaintiff's actions without paying for it. (4) (23) Articles 179 and 180 of the Egyptian Civil Law identified the concepts and remedies of unjust enrichment, under which ambush marketing can be specified (1)

As a business operation, sports sponsorship is a complex process that includes an intricate set of activities; leveraging and activation being the most critical. Sponsorship leveraging and activation are known as the marketing and promotional activities of the sponsor as they attempt to generate awareness of the benefits from their association between the event and its trademarks and images. Leveraging is often argued to be the most important measure a sponsor may take in order to earn and provide benefits through the mutually beneficial relationship between itself and the sponsees. As a result of rising sponsorship risks, event organizers have become increasingly proactive in their efforts to fight against such issues as media clutter and ambush marketing. (6)

\section{Review of literature:}

Maclentosh et al (2012) examined mega-sports event interest as a determinant of sponsorship and ambush marketing attitudes, as well as the purchase intention of affiliated properties during the 2010 Vancouver Olympic Winter Games. In total, 619 consumer surveys were collected from four different Canadian cities. Results showed that overall consumer interest was high, and that their purchase intention was strongly influenced by level of interest. (10) 
Hutter, K., \& Schwarz (2012) provide a causal model of ambush marketing focusing on cognitive and affective image and their effects on downstream variables such as attitudes and purchase intention. The results of an online-survey with 278 respondents show that for typical sports brands affective image has a stronger impact on attitude towards the ambusher brand. In contrast, for atypical sport brands cognitive image has a stronger impact on the evaluation of the ambusher. Further, a strong impact of attitude towards the ambusher brand on purchase intention has been identified. (9)

Seth (2010) examined ambush marketing as an intellectual property infringement and suitability of the current IP legislations to tackle it. Primary data such as case laws and secondary data such as articles and parallel provisions with regard to IPR have been referred, which show that due to the absence of principle legislations and case precedents, corporations indulging in ambush marketing are able to get away scot-free. To overcome this problem, various countries such as South
Africa, New Zealand, Australia, China, England, Brazil and Canada have brought out amendments or legislations defining 'ambush marketing' as a specific type of IPR infringement and fixing liability for the same. It is time that India considers introducing such a legislation not just because its peers have taken such a step but because in the light of large scale events being organized in the country, there is a need to protect legitimate sponsors. (21)

Mazodier, M., \& Quester (2010) examined the effect of ambush marketing disclosure on attitudes toward the ambusher's brand. The results of an experiment conducted to this end show that ambush disclosure negatively influences perceived integrity, affective response and purchase intention. Involvement in the event and attitudes toward sponsorship of an event both moderate consumers' response to ambush marketing.(12)

Mazodier et al (2012) examined the effects of ambush marketing disclosure over the attitudes towards ambushers. Two successive 
experiments were conducted. The first study used a student sample $(\mathrm{n}=120)$ and a fictitious brand. The second study used a before- and- after experiment with control groups $(n=480)$, using four real brands and print disclosure articles. Data was collected from six French metropolitan areas and analyzed using Repeated Measure ANOVA and MANOVA. Results indicated that Ambush marketing disclosure is associated with lower attitudes towards the ambusher's brand. Two variables moderate this effect: involvement in the event and attitude towards sponsorship, both of which worsen the negative influence of ambush disclosure on audiences' attitudes. (13)

Grady et al (2010) examined event-specific legislation from Beijing, Vancouver and London to determine the potential impact on various stakeholders of the Olympic movement. The impact of such legislation is analyzed to determine whether the creation of new legislation as an ambush marketing protection strategy properly balances the rights and interests of all stakeholders, including the local business community and host city's residents. (8)

\section{Research Importance:}

This research is very important for sponsors and sponsees as well, as protecting sponsorship rights is of major importance for both parties to insure effective investment in sponsorship contracts without any harm for the benefits of either parties from a third party; namely the ambushers. .

On the other hand, it is very important to identify the existence of this phenomenon in the Egyptian sports sponsorship market due to its harmful effects. In addition, it is very important to see if there are any legal penalties against ambushers and restitutions for sponsorship rights' holders to compensate their revenues being lost due to ambushing.

\section{Aim:}

The current research aims to identify and analyze ambush marketing in Egypt from the perspective of sponsors and sponsees.

\section{Research Questions:}

To achieve the research aim, the research poses the following four questions:

1. What sponsors and sponsees know about ambush marketing in general? 
2. What sponsors and sponsees know about legal aspects of ambush marketing?

3. What sponsors and sponsees know about the harms of ambush marketing?

\section{Methods:}

Approach:

The researcher used the descriptive (survey) approach as it is suitable for the purposes of this research.

Participants:

The research community included board members and marketing personnel of two sports clubs (Al-Ahly and AlZamalek) and four Egyptian sports federations (Football Basketball - Tennis and Table Tennis) in addition marketing personnel of five sponsoring companies (Vodafone Egypt - Etisalat Egypt - Pepsi - Juhaina Ceramica Cleopatra) as official sponsors of sports activities. $(\mathrm{n}=90)$

Participants $\quad(n=40) \quad$ were randomly chosen including (30) board members and marketing personnel of sports Equation (2) as shown in table (1).

Table (1): percentages and frequencies of experts' opinions using Louche Equation for the interview $(n=7)$ clubs and federations in addition to (10) marketing personnel representing sponsors. This makes the final number of research sample (40) persons. Another (15) persons from the same research community and outside the main sample were included as a pilot sample for validating the research tool (annex 3).

Data Collection Tool:

For the purposes of this research, the researcher developed a structured interview consisting of a number of open-ended questions and presented it to a group of experts in sports administration ( $\mathrm{n}=7)$ (annex 1). Validity and Reliability the interview:

Validity:

To calculate validity, the researcher presented the preliminary version of the interview to experts $(n=7)$ from 8-2-2014 to 13-2-2014 and calculated percentages and frequencies of experts' opinions using Louche 


\begin{tabular}{|c|c|c|c|c|}
\hline S & Question & $\mathbf{F}$ & $\begin{array}{c}\text { Agreement } \\
\text { percentage (\%) }\end{array}$ & $\begin{array}{l}\text { Validity } \\
\text { coefficient }\end{array}$ \\
\hline 1 & 1 & V & $1 \ldots$ & .99 \\
\hline r & r & V & $1 \ldots$ & .99 \\
\hline r & r & r & rᄉ.OV &.. $\mathrm{\Lambda}$ \\
\hline$\varepsilon$ & $\varepsilon$ & V & $1 \ldots$ & .99 \\
\hline 0 & 0 & V & $1 \ldots$ & .99 \\
\hline 7 & 7 & V & $1 \ldots$ & .99 \\
\hline V & V & r & YN.OV &. Y \\
\hline$\wedge$ & $\Lambda$ & V & $1 \ldots$ & .99 \\
\hline 9 & 9 & V & $1 \ldots$ & .99 \\
\hline 1 . & 1. & V & $1 \ldots$ & .99 \\
\hline 11 & 11 & V & $1 \ldots$ & .999 \\
\hline $1 Y$ & Ir & V & $1 \cdots$ & .99 \\
\hline r & r & V & $1 \ldots$ & .99 \\
\hline
\end{tabular}

Table (1) indicated that the percentage of agreement on interview questions ranged between $(28.57 \%)$ and $(100 \%)$. All questions except for questions (3 \& 7) were included. Validity coefficient according to Louche Equation ranged between (0.28) and (0.99). These values were acceptable for all questions except for questions $(3 \& 7)$ as the minimum acceptable value was (0.62). this reduced the number of questions from (13) to (11) questions.

\section{Reliability:}

To calculate the interview reliability, the research used test/retest procedure on a pilot sample of (15) persons from the same research community and outside the main sample. Table (2) shows correlation coefficients between test and retest of the interview questions. 
Table (2): correlation coefficients between test and retest of the interview questions $(\mathbf{n}=15)$

\begin{tabular}{|c|c|}
\hline $\mathbf{S}$ & Correlation Coefficient $(\mathbf{R})$ \\
\hline 1 &.$\wedge 9$ \\
\hline r &.$\wedge \wedge$ \\
\hline$r$ &.$\wedge \mathrm{V}$ \\
\hline$\varepsilon$ & $\because V T$ \\
\hline 0 & $\cdot . \wedge \Lambda$ \\
\hline 7 & .10 \\
\hline V & .91 \\
\hline$\Lambda$ & $\cdot \wedge \varepsilon$ \\
\hline 9 & $\cdot \wedge$. \\
\hline $1 \cdot$ &. .19 \\
\hline 11 & $\cdot . \wedge r$ \\
\hline
\end{tabular}

\section{$R$ table value on $0.05=0.51$}

Table (2) shows statistically significant correlation coefficients between test and retest of the interview questions as (R) calculated values ranged between $(0.73)$ and $(0.91)$ and this exceeds its table value.

Pilot Study:

The researcher applied the final version of the interview to a pilot sample $(\mathrm{n}=15)$ from $22-2-2014$ to $6-3-$ 2014 to fulfill the following objectives:

1. Calculate the reliability of the interview

2. Identify any difficulties for the main application

3. Calculate the duration of the interview

Results indicated that the interview is reliable. There no difficulties identified as participants understood the items easily. Time needed for the interview was (30) minutes. Main application:

The

researcher interviewed participants $(\mathrm{n}=40)$ from 8-3-2014 to 3-4-2014. Each participant received a copy of the questions and was interviewed at his/her workplace. All participants were asked to answer frankly all the questions. Responses of participants were tabulated for statistical treatment.

Statistical treatment:

The researcher used SPSS software to calculate the following: frequency percentage -correlation coefficient - Louche Validity coefficient. 


\section{Results:}

Tables (3) to (13) present participants answers (frequency and percentage) for the interview respective questions.

\begin{tabular}{|c|c|c|c|}
\hline & Response & $\overline{\mathbf{F}}$ & Percentage (\%) \\
\hline$\overline{A-}$ & A fraud crime & 20 & $\overline{50}$ \\
\hline B- & A scam crime & 5 & 12.5 \\
\hline $\mathrm{C}-$ & Not a crime at all & 5 & 12.5 \\
\hline D- & I don't know & 10 & 25 \\
\hline & Total & 40 & 100 \\
\hline
\end{tabular}

Table (4): In a sponsorship contract the first party is the sponsee and the second party is the sponsor. If a third party tried to advertise his/her products indirectly during the event being sponsored and without permission from the sponsor, this is considered ..........

\begin{tabular}{c|l|c|c}
\hline \hline & \multicolumn{1}{|c|}{ Response } & F & Percentage (\%) \\
\hline \hline A- & Ambush marketing & 25 & 62.5 \\
\hline B- & Seizing an easy benefit & 5 & 12.5 \\
\hline C- & $\begin{array}{l}\text { Violation of the contract from the first } \\
\text { party }\end{array}$ & 5 & 12.5 \\
\hline D- & $\begin{array}{l}\text { Disregard from the second party to protect } \\
\text { his/her rights }\end{array}$ & 5 & 12.5 \\
\hline \multicolumn{2}{l|}{ Total } & 40 & 100 \\
\hline \hline
\end{tabular}

Table (5): In a sponsorship contract the first party is the sponsee and the second party is the sponsor. This type of contracts

\begin{tabular}{c|r|c|c}
\hline \hline & Response & F & $\begin{array}{c}\text { Percentage } \\
(\%)\end{array}$ \\
\hline \hline A- & Indicates legal obligations of both parties & 5 & 12.5 \\
\hline B- & $\begin{array}{r}\text { Guarantees financial benefits for both } \\
\text { parties }\end{array}$ & 2 & 5.00 \\
\hline C- & $\begin{array}{r}\text { Provides legal protection for both parties' } \\
\text { rights }\end{array}$ & 7 & 17.5 \\
\hline D- & All that is mentioned above & 26 & 65.00 \\
\hline \hline
\end{tabular}


Table (6): What type of risk is represented by Ambush marketing?

\begin{tabular}{l|l|c|c}
\hline \hline & Response & F & Percentage (\%) \\
\hline \hline A- & Unbearable risk & 23 & 57.5 \\
\hline B- & A risk that should be handled & 12 & 30.00 \\
\hline C- & Marginal risk & 3 & 7.5 \\
\hline D- & No risk at all & 2 & 5.00 \\
\hline \multicolumn{2}{l}{ Total } & 40 & 100 \\
\hline \hline
\end{tabular}

Table (7): From your point of view, what is the most harmful ambushing practice?

\begin{tabular}{l|l|c|c}
\hline \hline & \multicolumn{1}{|c|}{ Response } & F & Percentage (\%) \\
\hline \hline A- & Forging sponsor's trademark & 5 & 12.5 \\
\hline B- & $\begin{array}{l}\text { Marketing products similar to the } \\
\text { sponsor's }\end{array}$ & 12.5 \\
\hline C- & $\begin{array}{l}\text { Advertising the third party's } \\
\text { products unlawfully inside event } \\
\text { place }\end{array}$ & 20 & 50 \\
\hline D- & $\begin{array}{l}\text { Advertising the third party's } \\
\text { products unlawfully near event } \\
\text { place }\end{array}$ & 10 & 25 \\
\hline
\end{tabular}

Table (8): Concerning crimes related to sponsorship rights in Egypt, Ambush marketing is

\begin{tabular}{|c|c|c|c|}
\hline & Response & $\mathbf{F}$ & Percentage $(\%)$ \\
\hline A- & High & 20 & 50 \\
\hline B- & Moderate & 5 & 12.5 \\
\hline $\mathrm{C}-$ & Low & 5 & 12.5 \\
\hline D- & I don't know & 10 & 25 \\
\hline & Total & 40 & 100 \\
\hline
\end{tabular}


Table (9): Concerning parties of ambush marketing, this practice is harmful for..........

\begin{tabular}{|c|c|c|c|}
\hline & Response & $\mathbf{F}$ & Percentage (\%) \\
\hline A- & Sponsors & 32 & 80.00 \\
\hline B- & Sponsees & 5 & 12.5 \\
\hline $\mathrm{C}-$ & Third party & 3 & 7.5 \\
\hline & Total & 40 & 100 \\
\hline
\end{tabular}

Table (10): Ambush marketing activities clearly appear in..........

\begin{tabular}{l|l|c|c}
\hline \hline & \multicolumn{1}{|c|}{ Response } & F & $\begin{array}{c}\text { Percentage } \\
(\boldsymbol{\%})\end{array}$ \\
\hline \hline A- & Matches of the Egyptian Football league & 2 & 5.00 \\
\hline B- & $\begin{array}{l}\text { Regional, continental and international } \\
\text { events held in Egypt }\end{array}$ & 6 & 15.00 \\
\hline C- & National teams' events & 3 & 7.5 \\
\hline D- & All that is mentioned above & 29 & 72.5 \\
\hline \multicolumn{2}{l|}{ Total } & 40 & 100 \\
\hline \hline
\end{tabular}

Table (11): Ambush marketing is a crime in Egypt according to

\begin{tabular}{r|r|r|c}
\hline \hline & Response & F & Percentage (\%) \\
\hline \hline A- & Criminal law & 5 & 12.5 \\
\hline B- & Sports law & 10 & 25 \\
\hline C- & Civil law & 20 & 50 \\
\hline D- & International law & 5 & 12.5 \\
\hline \multicolumn{2}{|c|}{ Total } & 40 & 100 \\
\hline \hline
\end{tabular}

Table (12): Does the Egyptian Sports Law include any articles concerning ambush marketing?

\begin{tabular}{|c|c|c|c|}
\hline & Response & $\mathbf{F}$ & Percentage (\%) \\
\hline A- & Yes & 5 & 12.5 \\
\hline B- & No & 30 & 75.00 \\
\hline C- & I don't know & 5 & 12.5 \\
\hline & Total & 40 & 100 \\
\hline
\end{tabular}


Table (13): Does the Egyptian Civil Law include any articles concerning ambush marketing?

\begin{tabular}{|c|c|c|c|}
\hline & Response & $\mathbf{F}$ & Percentage (\%) \\
\hline A- & Yes & 25 & 62.5 \\
\hline B- & $\mathrm{No}$ & 5 & 12.5 \\
\hline C- & I don't know & 10 & 25 \\
\hline & Total & 40 & 100 \\
\hline
\end{tabular}

\section{Discussion:}

In the light of this research aim and questions, it is clear from these results that ambush marketing is wellknown in Egypt as $62.5 \%$ of participants indicated that it is a crime although the some of them (20 participants) indicated correctly that it is a type of fraud while (5) participants indicated that it is a scam.

In addition

participants $(62.5 \%)$ knew exactly what ambush marketing is while the rest of participants (15) did not differentiate it from negligence, right violation or even getting a chance.

All participants are fully aware of the contract relation and its liability as (5) participants indicated that contracts protect responsibilities of both parties, (2) indicated that contracts guarantee benefits for both parties, (7) indicated that contracts protect rights of both parties while the rest of participants (26) mentioned the three aspects as a whole.

Participants are aware of the risk of ambush marketing. Nevertheless, (23) participants indicated that it is a high risk while participants indicated that it is a moderate risk and (3) participants indicated that it is a low risk. This indicates that participants' awareness towards the risks of ambush marketing is relatively high.

Concerning the practices of ambush marketing, (20) participants $(50 \%)$ indicated that the most dangerous practice of this concern is advertising a third party's products in places of events while (10) participants (25\%) indicated that the most dangerous practice of this concern is advertising a third party's products near places of events. Forging the sponsor's brand and marketing a similar 
product were also mentioned as illegal practices of ambush marketing (5 participants each).

Nearly (75\%) of participants indicated the prevalence of ambush marketing in Egypt as (20) participants $(50 \%)$ indicated a high percentage of occurrence while (5) participants (12.5\%) indicated a moderate percentage of occurrence and (5) participants (12.5\%) indicated a low percentage of occurrence. Anyway, (25\%) of participants still do not know about ambush marketing and this is relatively risky percentage.

Concerning the damage of interest due to ambush marketing, (32) participants $(80 \%)$ indicated that it was harmful for sponsors while (5) participants $(12.5 \%)$ indicated that it was harmful for sponsees and (3) participants $(7.5 \%)$ indicated that it was harmful for the ambusher.

According to participants' responses, ambush marketing activities can be seen during the Egyptian football league matches, regional, continental and international events held in Egypt and events concerning national teams. This means that ambushers take all chances in all event and this is a serious damage.

Only half of the participants knew that ambush marketing can form a legal suit under the civil law in Egypt as (5) participants mentioned the criminal law, (10) participants mentioned the sports law, (5) participants mentioned the international law while (20) participants mentioned the civil law.

Most participants $(\mathrm{n}=30)$ $(75 \%)$ indicated that the sports law in Egypt does not include any articles concerning ambush marketing while participants $(62.5 \%)$ indicated that the civil law includes articles concerning ambush marketing under the articles (179) and (180) of Unjust Enrichment.

\section{Conclusions:}

In the light of this research aim, questions, methodology and results, the researcher managed to conclude the following:

1. Ambush marketing is well-known in Egypt

2. Sponsoring contract relation and its liability include protecting responsibilities of both parties, benefits for both 
parties and rights of both parties.

3. Participants' awareness towards the risks of ambush marketing is relatively high.

4. The most dangerous practice of this concern is advertising a third party's products in places of events, advertising a third party's products near places of events, forging the sponsor's brand and marketing a similar product

5. Ambush marketing is prevalent in Egypt

6. Ambush marketing is harmful for sponsors, sponsees and the ambushers as well.

7. Ambush marketing activities can be seen during the Egyptian football league matches, regional, continental and international events held in Egypt and events concerning national teams.

8. Ambush marketing can form a legal suit under the civil law in Egypt

9. The sports law in Egypt does not include any articles concerning ambush marketing while the civil law includes articles concerning ambush marketing under the articles (179) and (180) of Unjust Enrichment.

\section{Recommendations:}

According to this research results and conclusions, the researcher recommends the following:

1. Sponsors and sponsees should be educated about their right and responsibilities towards facing ambush marketing.

2. The sports law needs to be amended to include articles concerning ambush marketing according to the international experiences in this field.

3. Penalties and restitutions for ambush marketing should be strengthened to deter ambushers.

4. Ambush marketing should be considered under the "Protection of Intellectual Rights" act.

5. Investors working in the field of sports sponsoring should be educated about the harmful effects to all parties including ambushers themselves.

\section{References:}

1- Al-Sanhoury, Abd ElRazek (1958): Encyclopedia of the Egyptian Civil Law, Part I, Munshaat Al-Maaref, Alexandria - Egypt (2003 ED), P: 239 (in Arabic)

2- Brodsky, E., \& Darkhovsky, B. S. (2013). Non-parametric 
statistical diagnosis: problems and methods (Vol. 509). Springer Science \& Business Media.

3- Burton, R., Quester, P.G., \&Farrelly, F.J. (1998). Organizational power games. Marketing Management, Spring, International Journal of Sport Management, Recreation \& Tourism 7(1), P.P. 27-36.

4- Calamari, John D., and Joseph M. Perillo. 1999. Cont racts. $3 \mathrm{~d}$ ed. St. Paul, Minn.: W est

5- Chadwick, S., \& Burton, N. (2011). The evolving sophistication of ambush marketing: A typology of strategies. Thunderbird

International Business

Review, 53 (6), 709-719.

6- Ellis, D., Scassa, T., \& Séguin, B. (2011). Framing ambush marketing as a legal issue: an Olympic perspective. Sport

Management Review, 14(3), 297- 308.

7- Gardiner, S., O'Leary, J., Welch, R., Boyes, S., and Naidoo, U. (2012): Sports Law, Fourth Edition, Rutledge, P: 329

8- Grady, J., McKelvey, S., \& Bernthal, M. J. (2010). From Beijing 2008 to London 2012: Examining event-specific
Olympic legislation vis-à-vis the rights and interests of stakeholders. Journal of Sponsorship, Feb2010, Vol. 3 Issue 2, p144-156.

9- Hutter, K., \& Schwarz, U. (2012). Image effect of ambush marketing: The case of FIFA Soccer World Cup 2010. Proceedings of the Australian \& New Zealand Marketing Academy (ANZMAC) 2012, December 3rd-5th, Adelaide, Australia.

10- MacIntosh, E., Nadeau, J., Seguin, B., O'Reilly, N., Bradish, C. L., \& Legg, D. (2012). The role of megasports event interest in sponsorship and ambush marketing attitudes. Sport marketing quarterly, 21(1), 43.

11- Marketing, A. (2011). Ambush marketing and the right of association: Clamping down on references to that big event with all the athletes in a couple of years. Journal of Sport Management, 25, 354370.

12- Mazodier, M., \& Quester, P. (2010). Ambush marketing disclosure impact on attitudes toward the ambusher's brand. Recherche et Applications en Marketing (English Edition), 25(2), 51-67. 
13- Mazodier, M., Quester, P., \& Chandon, J. L. (2012). Unmasking the ambushers: conceptual framework and empirical evidence. European Journal of Marketing, 46(1/2), 192-214.

14- Meenaghan, T. (1996). Ambush marketing-A threat to corporate sponsorship. Sloan Management Review, P.P. 102-113.

15- Nufer, G. (2013). Ambush marketing in sports. Routledge. 16- O'Reilly, N., Seguin, B., (2009): Sport Marketing, A Canadian Perspective, Nelson, P: 284

17- Paul O'Sullivan \& Patrick Murphy (1998): Ambush marketing: The ethical issues. Psychology and Marketing, 15(4), P.P. 349366.

18- Pitt, L., Parent, M., Berthon, P., \& Steyn, P. G. (2010). Event sponsorship and ambush marketing: Lessons from the Beijing Olympics. Business Horizons, 53(3), 281-290.

19- Richard Verow, Clive Lawrence and Peter McCormick, (2005): Sports Business, Law, Practice and Precedents, second edition, Jordans
20- Sandler, D. and Shani, D (1989): Olympic sponsorship vs. ambush marketing: Who gets the gold? Research, Volume 29, Number 4, P.P. 914

21- Seth, R. (2010). Ambush marketing - need for legislation in India. Journal of intellectual property rights, 15 (6), 455-463.

22- Simon Rines, (2001): International Marketing Reports, Guinness Rugby World Cup Sponsorship; A Global Platform for Meeting Business Objectives, International journal of sport and sponsorship, Volume 3, Number 4, December 2001

23- Smith, Stephen A. 2003. "The Structure of Unjust Enrichment Law: Is Restitution a Right or a Remedy." Loyola of Los Angeles Law Review36 (winter)

24- Steve McKelvey, John Grady, (2008): Sponsorship Program Protection Strategies for Special Sport Events: Are Event Organizers Outmaneuvering Ambush Marketers? Journal of Sport Management, Volume 22, Issue 5, September, P.P. 550 586 